\title{
The SEC rules historical cost accounting: 1934 to the 1970s
}

\author{
Stephen A. Zeff*
}

\begin{abstract}
From its founding in 1934 until 1972 the SEC, and especially its Chief Accountant, disapproved of most upward revaluations and general price-level restatements of fixed assets as well as depreciation charges based thereon. This article is a historical study of the evolution of the SEC's policy on upward revaluations and restatements of non-financial assets. It treats episodes prior to 1972 when the private-sector bodies that established accounting principles sought to gain a degree of acceptance for such revaluations and restatements but were consistently rebuffed by the SEC. The SEC reversed its policy on upward revaluations during the period from 1972 to the end of the 1970s. Throughout the article, the author endeavours to explain the factors that influenced the successive positions taken by the SEC.
\end{abstract}

It is well known that the United States has long been a bastion of predominantly historical cost accounting for inventories and fixed assets. Not so well known, however, is the fact that the US insistence on the use of historical cost accounting has emanated from the Securities and Exchange Commission (SEC) and has not always been a tenet held and advocated by leaders of the accountancy profession. It is the aim of this paper to trace the SEC's powerful influence over the predominance of historical cost accounting in the US from its founding in 1934 until the 1970s.

\section{Early evolution of the SEC's position on historical cost}

The SEC came into existence on 2 July 1934 and was charged with administering the Securities Act of 1933 and the Securities Exchange Act of 1934, the second of which established the SEC. ${ }^{1}$ This legislation empowered the SEC to set the rules and regulations to govern the reporting, accounting and disclosure of financial information by companies whose securities were quoted on any national securities exchange, including the contents of prospectuses and periodic filings with the Commission. The SEC created the position of Chief Accountant in the autumn of 1935, and after

*The author is the Herbert S. Autrey Professor of Accounting, Rice University, Houston, Texas, USA. Correspondence address: Jesse H. Jones Graduate School of Management, Rice University - MS 531, PO Box 2932, Houston, TX 77252-2932, USA. E-mail: sazeff@rice.edu. This paper is an outgrowth of the author's presentation at the Information for Better Markets conference, sponsored by the Institute of Chartered Accountants in England and Wales and held in London on December 18-19, 2006. The author is grateful to Kees Camfferman, Todd Johnson, seminar participants at Cardiff Business School, and an anonymous reviewer for useful comments on earlier drafts. a short search it named Carman G. Blough, a Certified Public Accountant and former academic and Wisconsin government employee who had joined the Commission's registration division in 1934, to the position on 1 December 1935 (Chatov, 1975:103; Cooper, 1980:22). He remained as Chief Accountant until May 1938, when he left the Commission. From 1944 to 1961, he served as the full-time Director of Research of the American Institute of Accountants (AIA, Institute) ${ }^{2}$

The person who effectively cemented the SEC's policy to insist upon historical accounting was Robert E. Healy (pronounced Haley). Prior to becoming one of the five founding SEC Commissioners in 1934, Healy had been Chief Counsel of the Federal Trade Commission (FTC) from 1928 to 1934 and directed the FTC's sixyear, Congressionally mandated investigation into the market manipulations by public utility holding companies, with heavy emphasis on their use of dubious accounting practices during the 1920s. In the end, the record of the investigation accumulated to 95 volumes.

Healy had been a justice on the Vermont Supreme Court, and President Calvin Coolidge, a Vermonter himself, selected his fellow Republican to direct the FTC's mammoth investigation. Joel Seligman, the SEC's historian, has written, 'The experience radicalised the conservative Healy. Shocked to find that 'you can capitalise in some States practically everything except the furnace ashes in the basement', he became an uncompro-

1 The Federal Trade Commission administered the Securities Act of 1933 from June 1933 until 1 September 1934, when this authority was transferred to the SEC.

${ }^{2}$ For a discussion of the role of the Chief Accountant in relation to the establishment of accounting principles, see the Appendix. 
mising advocate of accounting and public utility reform' (2003:108).

Healy was livid at the asset value write-ups that public utilities had been booking. It was not only the write-ups themselves, 'however arrived at' (as he said), that incensed him as much as the utilities' follow-on accounting practices. He complained of 'write-ups used to create income or to relieve the income accounts of important charges' (1938:1), which would be debited to the capital surplus account that had been credited with the write-ups. Dividends would sometimes be paid against this unrealised appreciation, and 'Very often unamortised debt discount was charged against a capital surplus so created, thus increasing the reported earnings of the company in future years' (Healy, 1939:4). He was driven to the conclusion that all upward departures from historical cost were veritably heinous. In testimony to a Congressional committee in April 1934, he said, 'I think the proper function of accounting is to make a historical record of events as they happen' (Stock Exchange Practices, 1934:7606). ${ }^{3}$ Later in the 1930s he wrote, 'I think the purpose of accounting is to account - not to present opinions of value' (1938:6).

Remarking on Healy's influence within the SEC, Carman Blough wrote as follows, 30 years later:

'One of the first members of the newly formed SEC to be appointed was a former General Counsel for the Federal Trade Commission who had been in charge of that Commission's very comprehensive investigation of the public utility holding companies. During that study the flagrant write-up policies of the holding companies and their subsidiaries and the havoc they caused when the crash came in 1929 and 1930 kept impressing themselves on the chief investigator to the point that their evil became almost an obsession with him....So strong were his convictions and so convincing were his arguments against write-ups that all of the other members of the Commission were persuaded to take a positive stand against them from the very first case in which the question arose.' (1967:10).

Homer Kripke, a distinguished legal scholar who was an SEC attorney in 1939-44, has written,

'Healy's strong views dominated the Commission in the 1930s and 1940s when it was still struggling to undo the effects of the indiscriminate departures from [historical] cost in the 1920s. They influenced a whole generation of

\footnotetext{
3 This passage was quoted, slightly amiss, in de Bedts (1964:93).

${ }^{4}$ Reflecting mainly on the Commission's early years, Barr and Koch (1959:181-2) have written, 'A review of the informal cases involving appraisals shows that the Commission usually effected the elimination of the appraisal'
}

SEC accountants, the seniors of whom had served during his incumbency, until the retirement of Andrew Barr as Chief Accountant in 1972. It would be unfair to attribute the SEC's position solely to Healy, since the position continued for over a quarter of a century after his death. His position became that of other commissioners and a long succession of staff members because it suited their needs to emphasise objectivity at the expense of other potential attributes of an accounting system.' (1979:182)

Healy served on the SEC from 1934 until his death in November 1946. His record of service as a Commissioner was the longest in the SEC's history. Blough's immediate three successors as Chief Accountant - William W. Werntz (1938-47), Earle C. King (1947-56), and Andrew Barr (1956-72) all had joined the Commission's accounting staff in the 1930s. Healy and like-minded Commissioners succeeded in instilling in them an aversion to upward departures from historical cost if they had not already held that view. In fact, Barr had studied under A. C. Littleton, at the University of Illinois, who was the intellectual leader of the historical cost school.

In a comprehensive study of write-ups, R.G. Walker found that, in the SEC's first several years, its staff discouraged write-ups, and the Commission rejected asset appraisals that were devoid of adequate supporting evidence, not so much because of the revaluation practice per se (1992:10-15). ${ }^{4}$ In some cases, notably Northern States Power Company, a divided Commission (with Healy in the minority) allowed appraisals if there was sufficient disclosure of the procedure used (Healy, 1938:2-3). Around 1937/38, however, the SEC and its accounting staff began to take a more unequivocal stance against write-ups and by the 1940 s were actively banning them. Walker wrote, 'It appears that the SEC had virtually eliminated write-ups from the accounting practices of its registrants by the mid-1940s' (1992:22). By 1970, Kripke would write, 'In effect the SEC has made it an exercise in futility for practicing accountants or anyone else to argue for revision of valuation methods in balance sheets or income statements' (1970:1189).

In 1936, the SEC received some academic support for its historical cost position when the American Accounting Association's executive committee, led by Association President Eric L. Kohler, published 'A tentative statement of accounting principles affecting corporate reports', which strongly endorsed 'original cost' for physical assets. The committee said, 'If values other than unamortised [historical] costs are to be quoted they should be expressed in financial statements only as collateral notations for informative purposes' (1936:189). The committee was explicitly crit- 
ical of revaluations and the use of adjustments for 'ordinary' changes in price levels. It is likely that the Association's executive committee was also recoiling from the indiscriminate asset write-ups in the 1920s.

Not surprisingly, SEC Chief Accountant Blough said in 1937 that he agreed with the Association's tentative statement (1937:30). Four years later, the Association published an important monograph written by two members of its 1936 executive committee, William A. Paton and A. C. Littleton, which contained an elegant conceptual rationale for the use of historical cost accounting. Yet in their final chapter, entitled 'Interpretation', the authors (chiefly Paton) objectively discussed the pros and cons of replacement cost accounting and 'common dollar' accounting. As to the latter, they said, 'At the most what is needed is a special report supplementing the usual periodic statements and designed to trace the main effects of general price movements upon the affairs of the enterprise' (1940:141), which was a heady proposal at that time. Of the two authors of the monograph, Littleton, at the University of Illinois, was, throughout his career, an arch historical coster. Paton, at the University of Michigan, was a 'value' man..$^{5}$ The historical cost portion of this monograph became a standard text used in university accounting curricula and was widely read by practitioners as well.

\section{Developments in the 1940s and 1950s: the SEC's position hardens}

\subsection{Write-ups}

In the context of the SEC's stiffening position on asset write-ups, the US body that established accounting principles (as standard setting was then known), the AIA's part-time Committee on Accounting Procedure, which was composed of 18 practitioners in accountancy firms and three academics, began addressing the question itself. In its Accounting Research Bulletin (ARB) No. 5, 'Depreciation on appreciation', issued in April 1940, the committee said, in less than categorical terms, 'Appreciation [on fixed assets] normally should not be reflected on the books of account of corporations' (461). It added, however, that, where such appreciation has been recorded, 'income should be charged with depreciation computed on the new and higher figures' (461). The editor of The Journal of Accountancy said that the topic of the Bulletin 'has proved to be a particularly thorny subject' ('Two new Research Bulletins',

\footnotetext{
${ }^{5}$ Letter from Paton to the author, dated 24 February 1979.

${ }^{6}$ An 'upward' quasi-reorganisation might be labelled today as an 'enhancement gain' as the opposite number of an impairment loss.
}

1940:427). In fact, there were four dissenters. Noteworthy among them was William Paton, who wrote that depreciation on appreciation should not be a determinant of net income 'except in cases where the appraisal is a feature of formal or quasireorganization' (467). The Bulletin contained only an inconclusive discussion of the pros and cons of allowing asset write-ups by means of a quasi-reorganisation.

The term 'quasi-reorganisation' refers to an accounting procedure by which a company in severe financial straits, with a deficit in retained earnings, could avoid the expensive process of a legal reorganisation by eliminating the deficit and writing down its net asset values to levels that are justified in the light of its economic prospects, as if the company were engaging in a fresh start. Thereby, the company would have the prospect of declaring dividends in future years. Today, we would use the term 'impairment loss' as the rough equivalent of the write-down in the net assets, although the procedure to be used in a quasi-reorganisation is much more elaborate and may require approval by the shareholders (see SEC, 1941; Davis and Largay, 1995)

By the middle of the 1940s, the committee began looking for ways to gain acceptance for upward departures from historical cost. In 1945, the committee unanimously resolved to elaborate on $A R B$ No. 5. The committee's proposal, made in the form of a resolution in October 1945, was intended to open the door to the acceptability of an 'upward' quasi-reorganisation when 'supported by convincing evidence and [when] effected with due formality' ('Annual Report', 1946:104). ${ }^{6}$ The argument was made that, since a company could liquidate itself and come into existence afresh by recognising contemporary current costs, whether higher or lower, in its balance sheet, why should it not be possible to establish a new basis of accountability without actually liquidating and relaunching the company? This may have been a tactic to 'blind-side' the SEC, which had accepted a 'downward' quasi-reorganisation. The committee intended to draft an Accounting Research Bulletin to reflect this unanimous view. Yet, the following year, the committee reported that it had decided to postpone the preparation of a formal Bulletin ('Annual Report', 1947:109). The reason was that SEC Chief Accountant William Werntz had publicly made known his antipathy to using the quasireorganisation to record a write-up of assets (1945:386-7). Instead, the committee was content to write a letter to the AIA's executive committee dated 20 October 1945, saying

'...a new cost may and should be recognised whenever a new basis of corporate accountability is established by reorganisation or quasi-reorganisation if the carrying value of assets on the 
books has ceased to be representative of their value. ${ }^{7}$ (the letter was reproduced in Research Department, 1950:390)

Five years later, in 1950, the committee returned to the question, following the high post-war inflation. It decided, again unanimously, to draft a Bulletin to recommend quasi-reorganisation accounting that would allow write-ups. But the SEC scotched the initiative yet again by advising the committee that it would not accept financial statements with write-ups of the kind envisaged in the proposed Bulletin. Hence, the Bulletin was never issued (see Zeff, 1972:156-7).

When SEC Chief Accountants criticised upward departures from historical cost, it was customary that they raised the spectre of the indiscriminate write-up practices of the $1920 \mathrm{~s}$, as if it were a nightmare that should not be experienced again.

It was apparently of no moment to the SEC's Chief Accountant that an 'upward' quasi-reorganisation had won the support of two of the intellectual leaders of the profession. The doyen of the accountancy profession, George O. May, a retired partner of Price, Waterhouse \& Co. and a member and a former vice-chairman of the Committee, had given support to such a procedure in a major book (1943:99). William Paton, who was a member of the Committee from 1939 to 1950 , had been writing since 1940 that there was an urgent need to allow an 'upward' quasi-reorganisation in order to correct for historical costs that were out of line with current economic realities (see Zeff, 1979:115, 122-6).

Between these two ill-fated attempts to issue a Bulletin in favour of 'upward' quasi-reorganisations, which were crushed by explicit opposition from the SEC, the Committee faced the question of accounting for the effects of the high post-war inflation on depreciation. In 1947, several major companies, including United States Steel, DuPont, Allied Chemical \& Dye, and Sears Roebuck, opted to record depreciation at replacement cost in their financial statements. Industry was concerned that companies with a sizable depreciation charge were significantly overstating their reported earnings. Such earnings reports, companies believed, would be a stimulus for encouraging labour unions, which had been prevent-

\footnotetext{
${ }^{7}$ It is not clear what authority such a letter would possess, although it may be assumed that the SEC's accounting staff knew of it. In effect, by sending the letter instead of issuing an Accounting Research Bulletin, the Committee was registering its view without 'officially' proposing a practice to be followed.

${ }^{8}$ The abstaining party was William Paton, who wrote to the author on 6 December 1971 that he left the Committee's meeting room in despair during the discussion prior to taking the vote.
}

ed from pursuing negotiations over wages during the war, to press for significant wage increases and pension benefits. Also, major companies sought a way of defending themselves against public criticisms that they were profiteering at the public's expense (see Smith, 1955:172, 363-5, Appendix B; Depreciation Policy When Price Levels Change, 1948). Finally, industry hoped that the use of replacement cost depreciation in their financial statements might persuade Congress to give them comparable relief from being taxed on capital. But SEC Chief Accountant Earle King, as could be predicted, immediately objected to these upward departures from historical cost (1947a:22), which prompted US Steel instead to adopt accelerated historical cost depreciation on its postwar expenditures for property, plant and equipment, which, as it happens, produced financial results that were not all that different from the use of replacement cost depreciation (see McMullen, 1949; Blough, 1947). King was content with this tactical shift adopted by US Steel (1950:43). Congress, like the SEC, preferred the objectivity of historical cost, and in 1954 it struck a compromise by introducing two new methods of accelerated depreciation on historical cost into the income tax law.

Because of the suddenness of the decision of these major companies in 1947 to adopt replacement cost depreciation in the determination of earnings, the Committee had to act quickly to express its view as soon as possible. After the rebuff administered by the SEC two years earlier to the Committee's attempt to sanction write-ups under the head of quasi-reorganisations, it is likely that some Committee members who favoured the use of replacement cost depreciation would have voted against it because of expected opposition of the SEC. Therefore, it is difficult to know whether all of the Committee members were voting their genuinely held views. The Committee reacted quickly by publishing a statement in the October 1947 issue of The Journal of Accountancy (Committee on Accounting Procedure, 1947). The Committee re-issued this statement as Accounting Research Bulletin No. 33, entitled 'Depreciation and high costs', dated December 1947. The Committee's decision, which was taken with one qualified assent and one abstention, ${ }^{8}$ was that any depreciation in excess of normal historical cost depreciation for the year should be recorded 'below the line', meaning as an appropriation of net income or surplus and not as a deduction in arriving at net income. It said that "consideration of radical changes in accepted accounting procedure should not be undertaken, at least until a stable price level would make it practicable for business as a whole to make the change at the same time'. Of course, by the time a stable price level were to 
be achieved, the opponents of an upward departure from historical cost depreciation could dismiss the issue as no longer urgent. SEC Chief Accountant King, who had attended the Committee's meeting, publicly lauded the Committee's statement (1947b:127-8). ${ }^{9}$

In October 1948, the Committee, stung by criticisms made of $A R B N o .33$ at the Institute's annual meeting the previous month, ${ }^{10}$ reaffirmed its position on replacement cost depreciation in a letter to Institute members (Committee on Accounting Procedure, 1948). But by then the vote attracted four dissenters - the chairman who was the senior technical partner at Peat Marwick (Samuel J. Broad), two well-known partners from middle-sized firms (Maurice E. Peloubet and C. Oliver Wellington, a former chairman of the Committee), and an accounting professor (Paton). These four disagreed with the Committee's view that "no basic change in the accounting treatment of depreciation of plant and equipment is practicable or desirable under present [inflationary] conditions' (1948:381). This was the first time in the Committee's history that its chairman had registered a dissent. But, as always, the SEC won the day. In the same issue of The Journal of Accountancy in which the Committee's letter was reproduced, the editor defended the Committee's position at length in an editorial ('Institute Committee', 1948).

During the 1940s, the American Accounting Association twice published revisions of its 1936 'principles' statement, in 1941 and 1948 ('Accounting principles', 1941; 'Accounting concepts and standards', 1948). Both reaffirmed the 'cost principle'. As in 1936, they were critical of revaluations, and they said that the country's experience with changing price levels did not warrant making adjustments for such changes. Again, as in 1936, they relegated values other than historical cost to supplementary disclosures. In its 1941 Annual Report, the SEC applauded the 1941 revision (SEC, 1942:198; see also Werntz, 1941:315).

\footnotetext{
${ }^{9}$ King wrote, '[Assistant Chief Accountant Andrew] Barr and I were present at the meeting at which this release was decided upon and it was strongly advocated by us'. Letter from Earle C. King to The Commission, dated 22 October 1947 (in the author's files).

${ }^{10}$ Prominent among those who criticised ARB No. 33 during the annual meeting was George O. May, who had been privately counselling U.S. Steel on the wording of the disclosures relating to its replacement cost depreciation charge, with which he agreed. Another critic, who spoke on the floor of the annual meeting, was William Blackie, a CPA, who was vice president of Caterpillar Tractor Co. See Blackie (1948). Interview with Carman Blough, January 1967. See also Papworth (1948:383-4).

${ }^{11}$ Chief Accountant King had earlier recommended that the Committee on Accounting Procedure publish a comprehensive statement of accounting principles (1948).
}

In its 1948 Annual Report, the SEC mentioned the 1948 revision in a favourable light (SEC, 1949:112).

For its part, the SEC took a step in 1950 towards making permanent its requirement that historical cost be used in registrants' financial statements. It announced a general revision of its Regulation $S$ - $X$, which governs the contents of financial reports filed with the Commission and until then had dealt chiefly with matters of disclosure and display. The proposed revision incorporated a number of substantive accounting policy positions that had been dealt with during the 1940s in Accounting Series Releases. These included a new provision that said, 'Except as otherwise specifically provided, accounting for all assets shall be based on cost' ('Security [sic] and Exchange Commission', 1950:160). The effect of this new provision would change an ad hoc position of the Commission on the use of historical cost to one that was set in stone. So strong was the negative reaction within the accountancy profession to many of the SEC's proposed changes in Regulation $S-X$, which included a rare expression of opposition from the assembled members at an annual meeting of the American Accounting Association (Zeff, 1966:64-5), that the SEC in 1951 withdrew the provisions dealing with accounting principles in the proposed revision of Regulation $S-X$ in return for an assurance that the Committee on Accounting Procedure would, among other things, codify its series of Bulletins (Zeff, 1972:158-9). ${ }^{11}$ Yet the SEC achieved its objective by another means: the revised Regulation S-X included a provision that in effect incorporated the Accounting Series Releases in the regulation (see Barr, 1979:51).

In 1953, the Committee issued Accounting Research Bulletin No.43, which was a restatement and revision of the Committee's previous Bulletins dealing with accounting principles and procedure. This was the codification sought by the SEC. Chapter 9A of the Bulletin was a reaffirmation of $A R B$ No. 33, but six of the 20 Committee members dissented, which was one vote short of defeating the reaffirmation. The dissenters included senior partners of Peat Marwick and Price Waterhouse, three well-known partners of middle-sized firms, and an academic. The Committee felt obliged to state in Chapter 9B of ARB No. 43 that, in cases where upward revaluations in depreciable assets had been recorded, the subsequent depreciation should be computed on the written-up amounts.

In the late 1940s and into the 1950s, there was disagreement within and among the largest accountancy firms on the propriety of using replacement cost depreciation. Evidently, Peat Marwick was opposed, but senior partners in Price Waterhouse and Arthur Andersen were at odds 
within their respective firms on the contentious subject. ${ }^{12}$

From 1954 to 1958 , consecutive subcommittees of the Committee on Accounting Procedure laboured to develop a Bulletin that would allow the upward revaluation of assets, using the analogy of a quasi-reorganisation. Curiously, these efforts had been encouraged by a suggestion from SEC Chairman J. Sinclair Armstrong that it would be helpful to have an authoritative statement of the circumstances in which upward departures from historical cost might be justified (see Armstrong,

${ }^{12}$ Two successive senior technical partners at Peat Marwick, Samuel Broad and John Peoples, dissented from the Committee on Accounting Procedure's letter reaffirming $A R B$ No. 33 and Chapter 9A in $A R B$ No. 43, respectively. In Price, Waterhouse (PW), John B. Inglis, who gave US Steel a qualified report in 1947 because of its use of replacement cost depreciation, voted in favour, but the redoubtable George O. May, by then retired but very much an active thinker and writer, and his protégé in the firm, Paul Grady, together with several other senior PW partners were opposed. In Arthur Andersen, Paul K. Knight, a partner in the firm's New York office and a member of the committee, was in favour, while Leonard Spacek and the partners in the Chicago home office were opposed. The academic who opposed Chapter 9A was C. Aubrey Smith, of the University of Texas, who had spent the summer of 1935 in the SEC's registration division. From outward appearances, the leading partners in Ernst \& Ernst, Haskins \& Sells, and Lybrand, Ross Bros. \& Montgomery were in favour of the position adopted in ARB No. 33 and in Chapter 9A of ARB No. 43.

${ }^{13}$ Report of the Committee on Accounting Procedure, dated 30 September 1958 (in the author's files). As it happened, the Committee chairman at that time was former SEC Chief Accountant Werntz, by then a partner in a major accountancy firm

${ }^{14}$ An early indication of this interest was the publication in April 1949 by the AIA's Research Department of a memorandum entitled 'An inquiry into the reliability of index numbers', which was originally intended 'for use as background material for consideration by the committee on accounting procedure in its deliberations as to the feasibility of using index numbers for adjustment of depreciation and/or property carrying values' (Research Department, 1949:312 ftn 1).

15 The Study Group was sponsored by the Institute and was financed jointly by it and the Rockefeller Foundation. It was composed of businessmen, lawyers, economists, statisticians, and others, as well as accountants.

${ }^{16}$ In the UK, GPL accounting became known as Current Purchasing Power (CPP) accounting. GPL accounting was not regarded by theorists as a departure from historical cost accounting but instead as an adaptation of historical cost accounting to inflationary conditions.

${ }^{17}$ The petition was transmitted in a letter to the Commission on 24 March 1954 and was signed by Leonard Spacek on behalf of the firm. Curiously, the SEC, when reporting on the petition in its next Annual Report, erroneously referred to the petition as calling for 'economic depreciation (based on replacement at current prices)' (SEC, 1955:107). Perhaps Chief Accountant King did not fully appreciate the difference between GPL-restatements and replacement cost adjustments.

${ }^{18}$ Letter from Orval L. DuBois, Secretary, Securities and Exchange Commission, to Leonard Spacek, dated 28 May, 1954. The firm's petition, as well as the letter from DuBois, is in the author's files. The term 'substantial authoritative support' has been used by the SEC since 1938 as the criterion for sound accounting practice. See the SEC's Accounting Series Release No. 4 (1938), which continues to be in effect today.
1956:159-60). Yet in 1958, by which time Armstrong was no longer on the Commission, the SEC's accounting staff signified to the committee that there was no need for such a general statement. Thereupon, the committee removed the project from its agenda. ${ }^{13}$

\subsection{General price-level accounting}

Since the late 1940s, interest had been growing in the use of general price-level adjustments applied to historical cost, rather than the use of current cost, to reflect the impact of the increase in prices on financial statements. ${ }^{14}$ Perhaps a reason for this different tack, in the minds of some, was the hope that the SEC might view it as less open to objection than the use of current cost. In 1952, the report of the Study Group on Business Income, which was engineered by George O. May, recommended that "corporations whose ownership is widely distributed should be encouraged to furnish [supplementary] information that will facilitate the determination of income measured in units of approximately equal purchasing power', subject to audit where practicable (1952:105). ${ }^{15}$ SEC Chief Accountant King, who was a member of the broadly constituted Study Group, strongly dissented from this recommendation (1952:122-3). The Study Group's report provided encouragement for the emerging interest, stimulated by the earlier writings of Henry W. Sweeney (1936) and William Paton (1941), in general price-level (GPL)-restated financial information to deal with the recent run-up of inflation.

Beginning in 1953/54, under the aggressive leadership of Leonard Spacek, Arthur Andersen \& Co., which had a large client base in the public utility industry, was an outspoken advocate of current cost accounting or, alternatively, the use of GPL indices to restate historical cost depreciation. ${ }^{16}$ Indeed, in March 1954 the firm boldly petitioned the SEC to require companies to state in an audited footnote the amount by which net income failed to reflect GPL-restated depreciation of plant and property. ${ }^{17}$ In May 1954, the SEC denied the firm's petition, saying as follows:

'The Commission has concluded that [the firm's proposal] is not in accordance with sound and generally accepted accounting principles, that it does not have substantial authoritative support, and that its adoption is not necessary or appropriate in the public interest or for the protection of investors or consumers to carry out the provisions of the statutes administered by the Commission. ${ }^{18}$

A more categorical denial could hardly be imagined.

In the 1950s and 1960s, Spacek's activism led his firm to support the efforts of several of its pub- 
lic utility clients to record GPL-restated depreciation or current cost-adjusted depreciation in their financial statements, one client also doing a GPLrestatement of its fixed assets in the balance sheet (see Randall, 1974; Staff of the Accounting Research Division, 1963:194-9, 211-17). The companies' motivation was to show a reduced net income in the light of a larger investment base following the postwar inflation, so that this lower rate of return on assets would support their argument to regulators for higher energy rates to consumers. Yet those of its clients that were SEC registrants were required to relocate the depreciation charge 'below the line' in their filings with the Commission (Zeff, 1992:457-9; Goodrich, 1969). The SEC insisted that a company's reported earnings must reflect depreciation based on conventional historical cost.

Apart from its work with audit clients, Andersen issued a series of publications from 1959 onwards in which it advocated one or another form of pricelevel depreciation, price-level accounting, and eventually 'value accounting' (Memorandum on Price-Level Depreciation, 1959; Accounting and Reporting Problems of the Accounting Profession, 1969:5-16; Objectives of Financial Statements, 1972).

Also during the 1950s, the American Accounting Association, the organisation of accounting academics, took up the cause of GPL-restated financial reporting. In 1951, an Association committee, which included a leading practitioner (Maurice $\mathrm{H}$. Stans, of Alexander Grant \& Company), recommended that companies include comprehensive GPL-restated financial statements as supplementary information to their primary statements ('Price level changes and financial statements', 1951). In 1955-56, the Association published three monographs that explained and illustrated GPL-restated financial statements and argued their merits (Mason, 1955; Jones, 1955; Jones, 1956).

In 1957, the Association committee charged with revising its 'principles' statements turned a corner, departing from the Association's three previous 'principles' statements on whether to provide GPL-restated information. The committee, chaired by Robert K. Mautz of the University of Illinois, recommended that investors should be furnished with supplementary data 'to reflect the effect of price changes in the specific assets held by the enterprise during the period, to show the effect upon the enterprise of movements in the general price level, or to achieve both purposes' (Committee on

\footnotetext{
${ }^{19}$ Sidney Davidson, who was a member of the APB at that time, has confirmed this reason for the change from an Opinion to a Statement. Telephone conversation with Davidson on 31 December 2006.

20 Accounting Principles Board, Minutes of meeting 16-18 August 1967, p.10 (in the author's files).
}

Accounting Concepts and Standards, 1957:544). After having indicated its positive view on the Association's three previous 'principles' statement, the SEC was conspicuously silent in its Annual Reports about whether it endorsed the Association's most recent statement. Chief Accountant Barr would write in 1959, begrudgingly, that the SEC 'probably would not object to the inclusion of such [GPL-restated] statements as supplementary material in a filing with the Commission' (Barr and Koch, 1959:182).

During the 1960s, the Accounting Principles Board (APB), which had succeeded the Committee on Accounting Procedure in 1959, became interested in GPL-restatements. In 1963, the APB sponsored the publication of a research study that explained and illustrated GPL-restated financial statements (Staff of the Accounting Research Division, 1963). In an APB research study published in 1965 and written by Paul Grady, a senior partner in Price Waterhouse, he carried forward the views of his late mentor, George O. May, by advocating a supplementary reporting of the financial effects of price-level changes (1965:370).

By the end of the 1960s, the APB added tempered support for GPL-restated financial statements as supplements to the primary statements. In 1969 , the APB unanimously approved a non-binding Statement to call for the supplementary disclosure of GPL-restated statements. Initially, the subcommittee that began in 1966 to draft the pronouncement understood that the board intended to issue it as a mandatory Opinion. Miller and Redding report that the pronouncement became a Statement when the board found that it was unable to secure a two-thirds majority for GPL-restatements as a required practice (1986:91). ${ }^{19}$ Had the APB issued an Opinion, the SEC would not have enforced compliance with it. Indeed, at the board's August 1967 meeting, LeRoy Layton, the chairman of the subcommittee, informed the board that SEC Chief Accountant Andrew Barr 'was generally not in favour of the positions taken in the draft Opinion principally because of the problems associated with (a) parallel statement presentation, (b) continued restatement of previous financial statements as general price indices change, which he believes would be baffling to readers and might be used as an excuse for 'appraisal accounting' by some persons, and (c) possible legal implications' ${ }^{20}$ In the event, few companies adopted the APB's recommendation.

As noted earlier, the periodic intervention of the SEC Chief Accountant on certain drafts of the Committee on Accounting Procedure and the APB, which occurred also on issues other than the ones that are germane to this article, raises a question whether Committee and APB members were voting their genuine beliefs or were bowing to the in- 
evitable, namely, the position espoused, or known to be held, by the Chief Accountant. ${ }^{21}$

\subsection{Further on upward departures from historical cost}

Those who might have hoped at the outset of the 1960s that the newly formed APB could open the door, if only slightly, to upward departures from historical cost accounting were rudely taken aback by the APB's peremptory rejection of its research study on accounting principles, today known as a conceptual framework document, which was published in 1962. The two academic authors of the study, Robert T. Sprouse and Maurice Moonitz, advocated the use of net realisable values or, alternatively, current replacement cost to measure merchandise inventory and the use of current replacement cost to measure plant and equipment (1962:27-34). The research study was received coolly, to say the least, by the members of the APB and by the advisory committee on the project. Indeed, three members of the advisory committee, former SEC Chief Accountants Blough and Werntz and the sitting Chief Accountant, Barr, totally rejected the authors' recommendations. ${ }^{22}$ Barr minced no words when he wrote, 'indiscriminate application of the [recommended] principles could result in false and misleading financial statements and might tend to undermine the confidence of the public in all published financial statements' (Sprouse and Moonitz, 1962:60). For its part, the APB discarded the research study and declined to consider it again ('Statement', 1962).

In 1963, Arthur R. Wyatt wrote an accounting research study on business combinations for the APB in which, among other things, he recommended a 'fair-value pooling' concept. This meant that, for business combinations effected by an issue of shares and where the constituents were of approximately equal size, the assets of both constituents should be restated at their fair values, up or down (1963:107). He insisted that this approach was 'applicable only when the facts of the transaction indicate clearly that the resultant entity is, in effect, a new enterprise' (107). Yet Chief

\footnotetext{
${ }^{21}$ In 1972, Charles T. Horngren, an academic and a member of the APB, argued: 'The SEC (top management) has used decentralisation with a master's touch. Its lower-level management (APB) does an enormous amount of work for no salary and has just enough freedom to want to continue the arrangement....the Board has been unjustifiably criticised for timidity or vacillation on several occasions when the basic explanation for the Board's behavior has been no assurance of support from the SEC' (1972:39).

${ }^{22}$ Blough was then a member of the APB, and Werntz, a partner in the firm of Lybrand, Ross Bros. \& Montgomery, had been the last chairman of the Committee on Accounting Procedure. Barr had been expressly authorised by the Commission to accept the invitation to serve on the advisory committee, which was an unprecedented instance of a Chief Accountant serving on an Institute committee.
}

Accountant Barr likened Wyatt's 'fair-value pooling' concept for business combinations to the upward quasi-reorganisations to which the SEC had objected some years ago (1965:24). Barr was ever on guard for what he regarded as 'upward' quasireorganisations in new guise.

In APB Opinion No. 6, issued in 1965, whose purpose was to declare the status of the previously issued Accounting Research Bulletins from No. 43 onwards, it was stated that, with respect to Chapters 9A and 9B of ARB No. 43, "property, plant and equipment should not be written up by an entity to reflect appraisal, market or current values which are above cost to the entity' but that 'Whenever appreciation has been recorded on the books, income should be charged with depreciation computed on the written up amounts' (APB, 1965:42). One of the APB members, Sidney Davidson, of the University of Chicago and a former student of Paton's, qualified his assent to the board's view that fixed assets should not be written up to reflect current costs 'but only because he feels current measurement techniques are inadequate for such restatement. When adequate measurement methods are developed, he believes that both the reporting of operations in the income statement and the valuation of plant in the balance sheet would be improved through the use of current rather than acquisition costs' (42).

In 1966, an American Accounting Association committee produced A Statement of Basic Accounting Theory (Committee to Prepare a Statement of Basic Accounting Theory, 1966). Among other things, it recommended that both historical and current costs be reported in the body of companies' financial statements (30-1, Appendix B). The author recalls a gathering during the Association's 1966 annual meeting, at which the committee presented its recommendations. During the meeting, SEC Chief Accountant Barr stated that the SEC would not accept such financial statements.

A possible reason why US companies may not have been greatly concerned over the impact on earnings of historical cost accounting during times of rising prices was the availability of last-in, firstout (LIFO) accounting for inventories as well as the use by a considerable number of companies of one or both of the accelerated methods of depreciation for financial reporting purposes following enactment of the Internal Revenue Code of 1954.

\section{Coping with the inflation of the 1970s - the SEC recants on current cost/value}

A major changing of the guard within the SEC occurred in 1972. Andrew Barr, the last of the Chief Accountants who had joined the SEC's accounting staff in the 1930s, retired. Instead of tapping A. Clarence Sampson, Barr's deputy whom he had in- 
tended to succeed him, SEC Chairman William J. Casey decided that he wanted to look outside the Commission for the next Chief Accountant. ${ }^{23} \mathrm{He}$ chose an activist, John C. (Sandy) Burton, an accounting and finance professor at Columbia University who had studied accounting at Haverford College with Philip W. Bell. It was Bell, together with Edgar O. Edwards, who wrote a highly influential book in 1961, The Theory and the Measurement of Business Income, in which they explained and advocated the use of current cost accounting. Burton was already on record as favouring a change in the traditional accounting model that would better depict economic reality (1971:50). Burton, at age 39, had not been an accountant during the 1930s and thus would not have been haunted, like his predecessors, by tales of the write-ups during the 1920s.

US inflation was high throughout the 1970s, and one of the earliest exposure drafts issued by the newly established Financial Accounting Standards Board (FASB), which succeeded the APB in July 1973, was entitled 'Financial reporting in units of general purchasing power' (1974). Prior to the issue of the exposure draft, the FASB had published a discussion memorandum and held a public hearing on the subject. The recommendation in the draft was that companies' conventional financial statements should include a comprehensive GPL-restatement of their statements. Almost immediately, SEC Chief Accountant Burton derided the FASB's 'Units of general purchasing power' proposal as 'PuPU accounting' (1975:70). He argued that GPL-restated financial statements would not provide investors with any better information than conventional statements. He observed that 'the impact of inflation falls with dramatic unevenness on various sectors of the economy and various parts of firms'. He added, 'It is essential that rapid movement take place in the direction of replacement cost accounting so that investors can perceive the effects of inflation on the activities of business enterprise' (70). Coming from the SEC, this was indeed a revolutionary call for reform.

Burton meant what he said. In August 1975, the SEC announced a proposed revision to Regulation $S$ - $X$ to require that a defined set of large companies make footnote disclosure of replacement cost information for cost of sales, inventories, depreciation, and productive capacity (SEC, 1975; 'SEC proposes', 1975). The proposal, affecting about 1,000 of the country's largest non-financial corporations, went into effect in March 1976, when the

\footnotetext{
${ }^{23}$ Interview with A. Clarence Sampson, conducted by Ernest Ten Eyck, 7 July 2005 (SEC Historical Society, at http://www.sechistorical.org/museum/oralhistories/index.php \#sampson).
}

SEC issued Accounting Series Release (ASR) No. 190 , thereby rebuffing the FASB, which had opted for GPL-restatements (SEC, 1976; 'SEC adopts', 1976). The SEC stated in the release that 'it did not and does not view its [1975] proposal as competitive with that of the FASB', because companies could adopt GPL-restatements in conjunction with historical costs or replacement costs. But Leonard M. Savoie, a former AICPA executive vice-president, wrote, 'I do not know of anyone who agrees with the Commission on that, and the FASB deferred action on its exposure draft' (1979:231). The SEC clearly had taken the initiative for dealing with the effects of inflation out of the FASB's hands.

Although the required replacement cost information was not to be reflected in the body of the financial statements and did not have to be subject to audit, this was nonetheless a historic deviation from the SEC's defence of the primacy of historical cost accounting. Charles Horngren, a close student of the US accounting standard-setting process, attested to the pivotal role played by the Chief Accountant:

'As chief accountant, John C. Burton persuaded the SEC to mandate fair values....strong influential leaders can make a difference, especially if they are at points of leverage in the process. And timing counts too. For example, as chief accountant of the SEC, Andrew Barr had a wellknown aversion to upward departures from historical costs. If Barr were sitting in Burton's chair in 1976, I wonder if the replacement cost requirements would have been issued.' (Horngren, 1986:38)

Under Burton's leadership, the SEC performed a role in the US similar to that played by the Sandilands Committee in the UK in 1975, when the latter suddenly refocused the field of debate from Current Purchasing Power accounting, which had been recommended by the Accounting Standards Steering Committee in a provisional standard, to current cost accounting (see Tweedie and Whittington, 1984, ch. 5).

In 1979, the FASB recovered its lost ground. It issued Statement of Financial Accounting Standards (SFAS) No. 33 (1979b), which called for the supplementary disclosure of both current cost and GPL-restated data, dubbing the latter as 'constant dollar accounting', which, like the SEC release, applied only to very large corporations. Accordingly, in October 1979, the SEC issued Accounting Series Release No. 271 to delete the disclosure requirements set out in ASR No. 190 once the FASB's SFAS No. 33 were to take effect. Although an FASB standard now governed practice, it had been much influenced by the SEC's powerful intervention. 
Later in the 1970s, the SEC took a further step away from its long embrace of historical cost accounting by calling for the required use of current value information for proven reserves in the body of the financial statements of oil and gas producers. ${ }^{24}$ The issue arose in the aftermath of the Arab Oil Embargo of the United States and other Western nations in 1973. Congress enacted the Energy Policy and Conservation Act (EPCA) of 1975, which directed the SEC, after receiving formal advice from the FASB, to eliminate the diversity of accounting practice used in oil and gas production. Until then, some producers would capitalise only the costs incurred in successful production, while expensing the costs associated with failed attempts at discovering oil or gas deposits. This method, used mainly by the large, vertically integrated oil and gas companies, is known as 'successful efforts costing'. Other producers would capitalise all of the costs associated with oil and gas exploration. This method, used mainly by the smaller companies, is known as 'full costing'.

In 1977, the FASB issued SFAS No. 19, which, by a 4-3 vote, recommended that only the 'successful efforts costing' method be permitted. In reaching its conclusion, the board was under considerable pressure from small and medium-sized oil and gas companies not to require the use of 'successful efforts costing' (Staubus, 2003: 185-6; Van Riper, 1994, ch.4). As required by the EPCA, the SEC held public hearings, covering 12 days and accumulating 2,700 pages of transcript, with all five members of the Commission in attendance. Furthermore, there was intense pressure brought on the SEC from the smaller oil and gas companies, much of which was transmitted through members of Congress and federal departments, such as Justice and Energy. They used all of their lobbying might to defend against the imposition of 'successful efforts costing', which, they believed, would make their earnings trend much more volatile. For one of the few times in the SEC's history, all of the Commissioners - who rarely are versed in accounting - personally became immersed in an accounting issue. ${ }^{25}$ Not being schooled in accounting, the Commissioners had no allegiance to historical cost accounting, and they believed that, for the oil and gas industry, it was market values, not historical costs, that were relevant to investors. Indeed, this view was pressed on them numerous times during the hearings. It helped that the Chairman, Harold M. Williams, al-

\footnotetext{
${ }^{24}$ For a full and authoritative treatment of this oil and gas accounting episode, see Gorton (1991).

${ }^{25}$ An earlier such hearing was on 22 November 1965, when the Commissioners met with a delegation from the APB to discuss the classification of the deferred tax credit, which led to the issue of Accounting Series Release No. 102 (SEC, 1965). For a discussion of this episode, see Zeff (2007).
}

though trained as a lawyer, had been formerly a business school dean and a board director of a major oil and gas company. The Commissioners also believed, as did their accounting staff, that neither 'successful efforts costing' nor 'full costing' was demonstrably superior to the other. Accordingly, in August 1978, the SEC issued Accounting Series Release No. 253, which said that steps should be taken to develop and implement 'reserve recognition accounting' (RRA), a variant of current value accounting, for required use in the body of oil and gas companies' financial statements. Under RRA, the unrealised holding gains and losses in value of proven oil and gas reserves were to be taken to earnings. For the first time since the founding of the SEC in 1934, the Commission required a class of registrants to depart from historical cost accounting in the body of their financial statements. Times had indeed changed, and by then the memories of the flagrant write-ups of the 1920s had faded.

The SEC said that, in the interim, until RRA is ready for implementation, oil and gas companies may continue using either 'successful efforts costing' or 'full costing'. Thereupon, the FASB felt it had no option but to issue SFAS No. 25 to suspend the effective date for the requirement in SFAS No. 19 to use 'successful efforts costing' (1979a).

Following the issue of the SEC's release, the major oil and gas companies began to bring pressure on the SEC not to require the use of current values for their proven oil and gas reserves because of its impact on the public's perception of their profitability at a time of steadily rising petrol prices and constricted supply. The Organisation of the Petroleum Exporting Countries (OPEC) was raising the price of crude each quarter, and the major refining and marketing companies were already being denounced in the media for their escalating profits. In the end, in February 1981, the SEC reconsidered its requirement that RRA be used in the body of producers' financial statements and instead announced its support of a move by the FASB to develop a comprehensive footnote disclosure that would reflect the principles implicit in RRA. The FASB issued that guidance in SFAS No. 69, issued in November 1982.

But the precedent had been set. In 1978, for the first time, the SEC had announced as a matter of policy that historical cost accounting was not always to be preferred over the use of current values in the body of companies' financial statements.

\section{Conclusion}

One can see from the foregoing analysis that the SEC established and restated its position time and again on the primacy of conventional historical cost accounting during its first 38 years (that is, until 1972), even when the Committee 
on Accounting Procedure or the Accounting Principles Board was disposed to approve upward adjustments in one manner or another from conventional historical cost. This posture of the SEC explains the deeply held attachment to historical cost accounting that one associates with US financial reporting during much of the 20th century. The year 1972 marked the arrival of a Chief Accountant who was unencumbered by memories of the indiscriminate write-ups of the 1920s and, moreover, had been tutored in the merits of current cost accounting. Owing to his proactive influence, the SEC approved the required use by more than one thousand large companies of supplementary replacement cost disclosures during the inflationary 1970s. The SEC took one major step further when, during an intense period of controversy over accounting for oil and gas exploration in the second half of the 1970s, it called for the integration of current values into the body of companies' financial statements as a better solution than arbitrating the supremacy of 'full cost costing' in relation to 'successful efforts costing'. In the 1970s, the SEC had entered a new era in the regulation of company financial reporting.

The record of the SEC's numerous and powerful intrusions into the process of establishing proper accounting practice for inventories and fixed assets does much to call into question whether the United States truly has had a private-sector process for establishing 'generally accepted accounting principles'.

\section{Appendix}

\section{The role of the SEC Chief Accountant in relation to the bodies that establish accounting principles}

The Chief Accountant is the principal adviser to the Commission on accounting and auditing matters. From 1937 to 1982, the Commission issued Accounting Series Releases to express its view on accounting and auditing matters and to report on enforcement actions taken by the Commission. The Office of the Chief Accountant, together with the Division of Corporation Finance, which oversees corporate disclosure of important information to the investing public, have, since 1975, issued Staff Accounting Bulletins to convey their interpretations and practices in administering the disclosure requirements of the federal securities acts.

While the SEC has stated that it looks to the private sector for leadership in the establishment of accounting principles, all parties know that the ultimate authority to establish those principles rests with the SEC, which, in most instances, usually means the Office of the Chief Accountant.

The American Institute of Accountants, at the urging of the Chief Accountant (Blough, 1967: 5-7), enlarged its Committee on Accounting Procedure in 1938-39 and invested it with authority to issue Accounting Research Bulletins $(A R B S)$, setting out its opinion on proper accounting practice, which came to be known as 'generally accepted accounting principles' (GAAP). Unless the Chief Accountant were to make known his disagreement with an $A R B$ or with the authoritative pronouncements of its successor bodies, it may be assumed that the SEC expects all publicly traded companies, known as registrants, to comply with them. As is made evident in this article, the Chief Accountant occasionally attended meetings of the committee, and he and his staff communicated on a regular basis, in writing and orally, with members of the committee and its research staff.

The Accounting Principles Board (APB), which succeeded the Committee on Accounting Procedure in 1959, was a senior technical committee of the American Institute of Certified Public Accountants, which adopted its new name in 1957. Its authoritative recommendations on GAAP were called Opinions. In addition, it issued several Statements that constituted non-binding advice. The SEC Chief Accountant and his staff maintained frequent contact with the APB and its staff but did not attend its meetings.

The Financial Accounting Standards Board (FASB), an independent standard-setting body overseen by a board of trustees, succeeded the APB in 1973. Its authoritative recommendations on GAAP are known as Statements of Financial Accounting Standards. As with the FASB's two predecessors, the SEC Chief Accountant and his staff have been in regular contact with the FASB and its staff. Some or all of the SEC Commissioners meet periodically with some or all of the FASB members, together with their respective staffs, and the Chief Accountant participates in meetings of the FASB's Emerging Issues Task Force and attends and speaks at the quarterly meetings of the FASB's advisory council. 


\section{References}

'Accounting concepts and standards underlying corporate financial statements: 1948 revision' (1948). The Accounting Review, 23 (4): 339-44.

Accounting Principles Board. (1965). 'Status of Accounting Research Bulletins'. Opinion No. 6. New York: American Institute of Certified Public Accountants. Accounting Principles Board (1969). 'Financial statements restated for general price-level changes'. Statement No. 3 . New York: American Institute of Certified Public Accountants.

'Accounting principles underlying corporate financial statements' (1941). The Accounting Review, 16 (2): 133-9. Arthur Andersen \& Co. (1959). Memorandum on PriceLevel Depreciation. Chicago: Arthur Andersen \& Co.

Arthur Andersen \& Co. (1969). Accounting and Reporting Problems of the Accounting Profession. 3d edition. Arthur Andersen \& Co.

Arthur Andersen \& Co. (1972). Objectives of Financial Statements for Business Enterprises. Arthur Andersen \& Co.

'Annual Report of the Committee on Accounting Procedure' (1946). Yearbook/American Institute of Accountants 1944-45. New York: American Institute of Accountants.

'Annual Report of the Committee on Accounting Procedure' (1947). Yearbook/American Institute of Accountants 1945-1946. New York: American Institute of Accountants.

Armstrong, J.S. (1956). 'Corporate accounting standards under federal securities laws'. The Ohio Certified Public Accountant, 15: 155-60.

Barr, A. (1965). 'The influence of government agencies on accounting principles with particular reference to the Securities and Exchange Commission'. The International Journal of Accounting Education and Research, 1 (1):15-33.

Barr, A. (1979). 'Relations between the development of accounting principles and the activities of the SEC', in W. Cooper and Y. Ijiri (eds), Eric Louis Kohler: Accounting's Man of Principles, 41-61. Reston, VA: Reston Publishing.

Barr, A. and Koch, E.C. (1959). 'Accounting and the S.E.C.' The George Washington Law Review, 28 (1): 176-93.

Blackie, W. (1948). 'What is accounting accounting for Now?' N.A.C.A. Bulletin, 29 (21), section 1: 1349-78.

Blough, C.G. (1937). 'The need for accounting principles'.

The Accounting Review, 12 (1): 30-7.

Blough, C.G. (1947). 'Replacement and excess construction costs', The Journal of Accountancy, 84 (4): 333-6.

Blough, C.G. (1967). 'Development of accounting principles in the United States'. In Berkeley Symposium on the Foundations of Financial Accounting, 1-14. Berkeley: Schools of Business Administration, University of California.

Burton, J.C. (1971). 'An educator views the public accounting profession'. The Journal of Accountancy, 132 (3): 47-53.

Burton, J.C. (1975). 'Financial reporting in an age of inflation'. Journal of Accountancy, 139 (2): 68-71.

Chatov, R. (1975). Corporate Financial Reporting: Public or Private Control? New York: The Free Press/Macmillan. Committee on Accounting Concepts and Standards (1957). 'Accounting and reporting standards for corporate financial statements, 1957 revision'. The Accounting Review, Vol. 32 (4):536-46.

Committee on Accounting Procedure (1940). 'Depreciation on appreciation'. Accounting Research
Bulletin No. 5. The Journal of Accountancy, 69 (6): 461-7.

Committee on Accounting Procedure (1947). 'Appropriation, not charges, recommended to cover inflated replacement cost'. The Journal of Accountancy, 84 (4): 289-90.

Committee on Accounting Procedure (1948). 'Institute committee rejects change in basis for depreciation charges'. The Journal of Accountancy, 86 (5): 380-1.

Committee on Accounting Procedure (1953). 'Restatement and revision of Accounting Research Bulletins'. Accounting Research Bulletin No. 43. New York: American Institute of Accountants.

Committee to Prepare a Statement of Basic Accounting Theory (1966). A Statement of Basic Accounting Theory. American Accounting Association.

Cooper, W.D. (1980). 'Carman G. Blough: A study of selected contributions to the accounting profession'. $\mathrm{PhD}$ dissertation completed at the University of Arkansas. Published as Carman G. Blough: Selected Contributions in Accounting. Atlanta: Georgia State University Press, 1982.

Davis, M.L. and Largay, J.A. III (1995). 'Quasi reorganization: Fresh or false start'. Journal of Accountancy, 180 (1): 79-84.

De Bedts, R.F. (1964). The New Deal's SEC: The Formative Years. New York: Columbia University Press. Depreciation Policy When Price Levels Change (1948). New York: Controllership Foundation.

Edwards, E.O. and Bell, P.W. (1961). The Theory and Measurement of Business Income. Berkeley, CA: University of California Press.

Financial Accounting Standards Board (1974). 'Financial Reporting in Units of General Purchasing Power'. Exposure Draft, December 31. Stamford, CT: Financial Accounting Standards Board.

Financial Accounting Standards Board (1977). 'Financial accounting and reporting by oil and gas producing companies'. Statement of Financial Accounting Standards No. 19. Stamford, CT: Financial Accounting Standards Board. Financial Accounting Standards Board (1979a). 'Suspension of Certain Accounting Requirements for Oil and Gas Producing Companies, an amendment of FASB Statement No. 19'. Statement of Financial Accounting Standards No. 25. Stamford, CT: Financial Accounting Standards Board.

Financial Accounting Standards Board (1979b). 'Financial reporting for changing prices'. Statement of Financial Accounting Standards No. 33. Stamford, CT: Financial Accounting Standards Board.

Financial Accounting Standards Board (1982). 'Disclosures about oil and gas producing activities, an amendment of FASB Statements 19, 25, 33, and 39'. Statement of Financial Accounting Standards No. 69. Stamford, CT: Financial Accounting Standards Board.

Goodrich, P.F. (1969). Letter. The Journal of Accountancy, 128 (6): 23-4.

Gorton, D.E. (1991). 'The SEC decision not to support SFAS 19: A case study of the effect of lobbying on standard setting'. Accounting Horizons, 5 (1): 29-41.

Grady, P. (1965). Inventory of Generally Accepted Accounting Principles for Business Enterprises. New York: American Institute of Certified Public Accountants. Healy, R.E. (1938). 'The next step in accounting'. The Accounting Review, 13 (1): 1-9.

Healy, R.E. (1939). 'Address before the Harvard Business School Alumni Association at its Ninth Annual Special Meeting, at Baker Library, Harvard Business School, Boston'. Typescript, 16 June. 
Horngren, C.T. (1972). 'Accounting principles: Private or public sector?' Journal of Accountancy, 133 (5): 37-41.

Horngren, C.T. (1986). 'Institutional alternatives for regulating financial reporting'. In R.H. Mundheim and N.E. Leech (eds), The SEC and Accounting: The First 50 Years, 29-51. Amsterdam: North-Holland.

'Institute committee holds to depreciation on cost' (1948). Editorial. The Journal of Accountancy, 86 (5):353-4.

Jones, R.C. (1955). Price Level Changes and Financial Statements: Case Studies of Four Companies. American Accounting Association.

Jones, R.C. (1956). Effects of Price Level Changes on Business Income, Capital, and Taxes. American Accounting Association.

King, E.C. (1947a). 'Footnotes to financial statements'. Virginia Accountant, 1: 9-22.

King, E.C. (1947b). 'Some current accounting problems'. Reproduced in A.R. Roberts (ed), Selected Papers of Earle C. King, 123-31. New York: Arno Press, 1980.

King. E.C. (1948). 'Need for definitive statement of accounting principles'. The Journal of Accountancy, 86 (5): 369.

King, E.C. (1950). 'Current accounting problems'. The Accounting Review, 25 (1): 35-44.

Kripke, H. (1970). 'The SEC, the accountants, some myths and some realities'. New York University Law Review, 45 (6): 1151-1205.

Kripke, H. (1979). The SEC and Corporate Disclosure: Regulation in Search of a Purpose. New York: Law \& Business, Inc./Harcourt Brace Jovanovich, Publishers.

Mason, P. (1955). Price-Level Changes and Financial Statements: Basic Concepts and Methods. American Accounting Association.

May, G.O. (1943). Financial Accounting: A Distillation of Experience. New York: Macmillan.

McMullen, S.Y. (1949). 'Depreciation and high costs: The emerging pattern'. The Journal of Accountancy, 88 (4): 302-10.

Miller, P.B.W. and Redding, R. (1986). The FASB: The People, the Process, \& the Politics. Homewood, IL: Irwin. Papworth, W.S. (1948). 'A summary of papers from the Institute's 1947-48 annual meeting'. The Journal of Accountancy, 86 (5): 382-8.

Paton, W.A. (1941) Advanced Accounting. New York: Macmillan.

Paton, W.A. and Littleton, A.C. (1940). An Introduction to Corporate Accounting Standards. American Accounting Association.

'Price level changes and financial statements' (1951). Supplementary Statement No. 2. The Accounting Review, 26 (4): 468-74.

Randall, R.F. (1974). 'Finally - Inflation accounting?' Management Accounting, 56 (5): 57-9.

Research Department (1949). 'An inquiry into the reliability of index numbers'. The Journal of Accountancy, 87 (4): 312-19.

Research Department (1950). 'Departures from the cost basis'. The Journal of Accountancy, 89 (5): 388-91.

Savoie, L.M. (1979). 'Some views of current activities of the Securities and Exchange Commission'. In D.E. Tidrick (ed), Leonard M. Savoie: Words from the Past, Thoughts for Today. New York: Garland Publishing, 1995.

'SEC adopts disclosure rules for replacement costs' (1976). Journal of Accountancy, 141 (5): 11.

'SEC proposes replacement cost disclosure' (1975). Journal of Accountancy, 140 (4): 22.

Securities and Exchange Commission (1938). 'Administrative policy on financial statements'. Accounting Series Release No. 4 (April 25). Washington:
Securities and Exchange Commission.

Securities and Exchange Commission (1941). 'Procedure in quasi-reorganization'. Accounting Series Release No. 25 (May 29). Washington: Securities and Exchange Commission.

Securities and Exchange Commission (1942). Seventh Annual Report of the Securities and Exchange Commission, Fiscal Year Ended June 30, 1941. Washington: United States Government Printing Office. Securities and Exchange Commission (1949). 14th Annual Report, Securities and Exchange Commission, 1948, Fiscal Year Ended June 30. Washington: United States Government Printing Office.

Securities and Exchange Commission (1955). 20th Annual Report, Securities and Exchange Commission, 1954, Fiscal Year Ended June 30. Washington: United States Government Printing Office.

Securities and Exchange Commission (1965). 'Balance Sheet Classification of Deferred Income Taxes Arising from Installment Sales'. Accounting Series Release No. 102 (December 7). Washington: Securities and Exchange Commission.

Securities and Exchange Commission (1975). 'Notice of proposed amendments to Regulation $\mathrm{S}-\mathrm{X}$ to require disclosure of certain replacement cost data in notes to financial statements (S7-579)'. Securities Act Release No. 5608/August 21; Securities Exchange Act Release No. 11608. Washington: Securities and Exchange Commission.

Securities and Exchange Commission (1976). 'Notice of adoption of amendments to Regulation $\mathrm{S}-\mathrm{X}$ requiring disclosure of certain replacement cost data'. Accounting Series Release No. 190 (March 23). Washington: Securities and Exchange Commission.

Securities and Exchange Commission (1978). 'Adoption of requirements for financial accounting and reporting practices for oil and gas producing activities'. Accounting Series Release No. 253 (August 31). Washington: Securities and Exchange Commission.

Securities and Exchange Commission (1979). 'Deletion of requirement to disclose replacement cost information'. Accounting Series Release No. 271 (October 23). Washington: Securities and Exchange Commission.

Securities and Exchange Commission (1981). 'Financial reporting by oil and gas producers'. Accounting Series Release No. 289 (February 26). Washington: Securities and Exchange Commission.

'Security and Exchange Commission proposes to revise its Regulation S-X which governs financial statements filed with it'. (1950). The Journal of Accountancy, 90 (2): 158-65.

Seligman, J. (2003). The Transformation of Wall Street: A History of the Securities and Exchange Commission and Modern Corporate Finance. 3d edition. New York: Aspen Publishers.

Smith, R.L. (1955). 'A case analysis of external accounting influence over managerial decisions'. Doctoral dissertation done at the Harvard Business School (August).

Sprouse, R.T. and Moonitz, M. (1962). A Tentative Set of Broad Accounting Principles for Business Enterprises. New York: American Institute of Certified Public Accountants.

Staff of the Accounting Research Division (1963). Reporting the Financial Effects of Price-Level Changes. New York: American Institute of Certified Public Accountants.

'Statement by the Accounting Principles Board' (1962). New York: American Institute of Certified Public Accountants, April 13. 
Staubus, G.J. (2003). 'An accountant's education'. The Accounting Historians Journal, 30 (1): 155-96.

Stock Exchange Practices (1934). Hearings before the Committee on Banking and Currency, United States Senate, 73d Congress, 2d Session, on S.Res. 84, S.Res. 56, and S.Res. 97, Part 16: National Securities Exchange Act (continued), March 23 to April 5. Washington: United States Government Printing Office.

Study Group on Business Income (1952). Changing Concepts of Business Income. New York: Macmillan.

Sweeney, H.W. (1936) Stabilized Accounting. New York:

Harper \& Brothers.

'A tentative statement of accounting principles affecting corporate reports' (1936). The Accounting Review, 11 (2): 187-91.

Tweedie, D. and Whittington, G. (1984). The Debate on Inflation Accounting. Cambridge: Cambridge University Press.

'Two new Research Bulletins' (1940). Editorial. The Journal of Accountancy, 69 (6):427-8.

Van Riper, R. (1994). Setting Standards for Financial Reporting: FASB and the Struggle for Control of a Critical Process. Westport, CT: Quorum Books.

Walker, R.G. (1992). 'The SEC's ban un upward asset revaluations and the disclosure of current values'. Abacus, 28 (1): 3-35.
Werntz, W.W. (1941). 'Progress in accounting'. The Journal of Accountancy, 72 (4):315-23.

Werntz, W.W. (1945). 'Corporate consolidations, reorganizations and mergers'. The New York Certified Public Accountant, 15 (7): 379-87.

Wyatt, A.R. (1963). A Critical Study of Accounting for Business Combinations. New York: American Institute of Certified Public Accountants.

Zeff, S.A. (1966). The American Accounting Association, Its First 50 Years. American Accounting Association.

Zeff, S.A (1972). Forging Accounting Principles in Five Countries: A History and an Analysis of Trends. Champaign, IL: Stipes Publishing Company.

Zeff, S.A. (1979). 'Paton on the effects of changing prices on accounting, 1915-55'. In S.A. Zeff, J. Demski, and N. Dopuch (eds), Essays in Honor of William A. Paton: Pioneer Accounting Theorist, 91-137. Ann Arbor, MI: Graduate School of Business Administration, The University of Michigan.

Zeff, S.A. (1992). 'Arthur Andersen \& Co. and the twopart opinion in the auditor's report: 1946-1962'. Contemporary Accounting Research, 8 (2): 443-67.

Zeff, S.A. (2007). 'The SEC preempts the Accounting Principles Board in 1965: The classification of the deferred tax credit relating to installment sales'. The Accounting Historians Journal, 34 (1):1-23. 